\title{
References
}

Aldinger, H. 1935: Geologische Beobachtungen im Oberen Jura des Scoresbysundes (Ostgrönland). Meddr Gronland 99, 1, $128 \mathrm{pp}$.

Spath, L. F. 1935: The Upper Jurassic invertebrate faunas of Cape Leslie, Milne Land. I. Oxfordian and Lower Kimmeridgian. Meddr Gronland 99, 2, $82 \mathrm{pp}$.

Walker, G. P. L. 1951: The amygdale minerals of the Tertiary lavas of Ireland. I. The distribution of chabazite habits and zeolites in the Garron plateau area, County Antrim. Mineralog. Mag. 29, 773-791.

\section{NOTES ON THE GLACIAL GEOLOGY OF EASTERN MILNE LAND, SCORESBY SUND, EAST GREENLAND}

\author{
Svend Funder
}

\section{Introduction}

During the summer of 1969 field work was begun with the aim of establishing a general chronology of Quaternary events in the Scoresby Sund region. This summer the work was concentrated on the eastern part of Milne Land (fig. 1).

The region under consideration is shown in fig. 9; it comprises a coastal zone of low rounded mountains $(400-600 \mathrm{~m})$ composed of crystalline rocks, and a central zone of high mountains $(1500 \mathrm{~m})$ of alpine topography where Tertiary basalts rest on a basement of crystalline rocks. South-east of a line from Mudderbugt to Charcot Havn the bedrock is Mesozoic sandstone. Milne Land is bordered to the east and south by the comparatively shallow (400-600 m deep) waters of Scoresby Sund and Hall Bredning; on all other sides this large island is bordered by over-deepened fjords (800-900 m deep - see hydrographic chart in Thorson, 1934). In the central part of Milne Land an ice cap - Puderne - is found.

Observations on the Quaternary geology of Milne Land were made during the expedition led by C. Ryder in 1891-92 (Bay, 1896). At the following other places in the Scoresby Sund region work on the Quaternary has been carried out: Jameson Land (Nordenskiöld, 1907), Kjove Land (Sugden \& John, 1965), Schuchert Dal (Cruikshank \& Colhoun, 1965; Schafer \& Hartshorn, 1965). Information on the Scoresby Sund region from written sources as well as from aerial photos has been compiled on the Quaternary Map of Greenland, 1:2 500000.

The present investigation is planned to be the first of a three-summer project which will also comprise studies in the coastal and in the interior parts of the re- 
gion. On the map fig. 9 the most significant field observations from this summer have been plotted. As place names are sparse in the region, it has been split up into areas denoted by Roman numbers; these will be referred to in the text.

\section{Methods of altitude measurement}

A theodolite was used for levelling in areas II and V; elsewhere a hand level was used at low levels and an altimeter at the higher ones, including most of those here described. Unfortunately the altimeter is very imprecise, and an error of \pm 10 $\mathrm{m} / 100 \mathrm{~m}$ elevation must be considered. The measurements were made with respect to what was judged to be mean high tide level (no Fucus or Balanus lines were encountered); however, as the tidal amplitude in the region is less than $2 \mathrm{~m}$, the possible error from this assumption is negligible.

\section{The Milne Land Stages}

This term is proposed for a period of glacial advances represented by glacial deposits in all areas. The glacial deposits include moderately well preserved moraine ridges with a scattered vegetation, kame terraces and outwash deposits. The relative date of these advances is determined by the intersection of these deposits by marine shorelines; thus the oldest stage seems to have taken place at the same time as the formation of shorelines at and above $110 \mathrm{~m}$ over present sea-level, and the youngest advance and subsequent retreat probably took place at the same time as the formation of shorelines $90 \mathrm{~m}$ above sea-level.

The oldest moraine ridges can be followed on the plateaus above the valleys from starting points $500-550 \mathrm{~m}$ above sea-level and sloping gently towards the coast. Some of these moraines were deposited from outlets from the Milne Land ice cap (areas II and III, the glaciers being merged between these areas), but it seems likely that others were deposited from major ice streams occupying the deep fjords around Milne Land (areas I and IV-V, the glaciers being merged between the latter two areas) and receiving tributaries from Milne Land.

No terminal moraines from the oldest advance have been observed; this is apparently due to the fact that all the glaciers had their fronts in water at the time. Evidence for this is seen in the shape and composition of the coastal parts of some of the moraines (areas II and IV). These are gently rounded banks composed of sorted sand and gravel with boulders which indicate deposition in water. All other moraine ridges from this advance die out near the coast at altitudes $110-130 \mathrm{~m}$ above present sea-level.

In area IV the transition from terrestrial to marine moraine is preserved. It takes place at $110 \mathrm{~m}$, giving a relative date for the advance in areas IV-V. In the other areas only minimum dates can be obtained by shorelines; these are found between 
$120 \mathrm{~m}$ (areas II-III) and $100 \mathrm{~m}$ (area I). Whether the difference of more than $10 \mathrm{~m}$ in the altitude of the shoreline intersection in areas II-III and in areas IV-V is due to tilting of the shoreline, or to the advance being slightly metachronous, cannot yet be established (see later discussion).

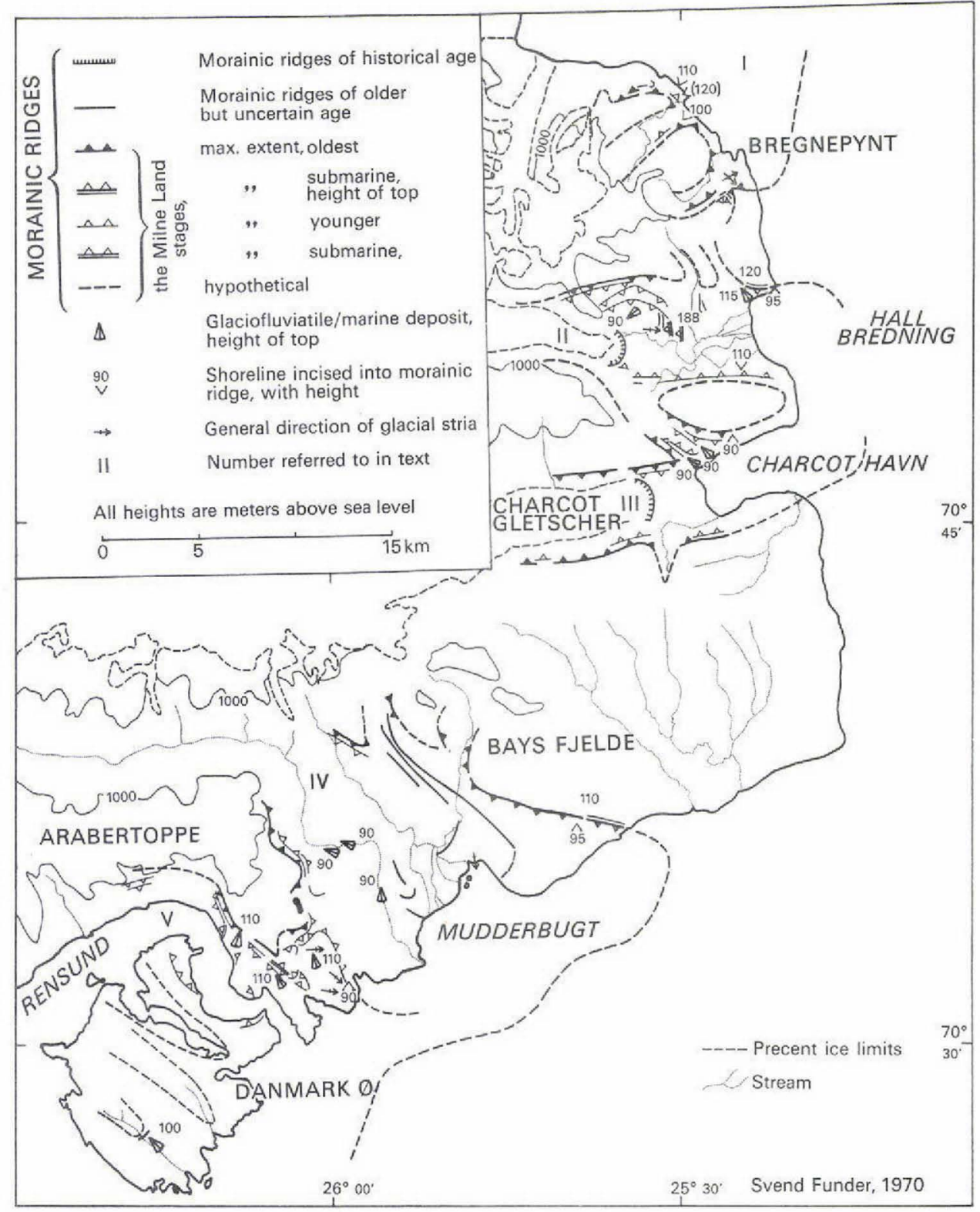

Fig. 9. Glacial geology of eastern Milne Land. 
After the retreat from these moraines the glaciers in this region apparently never again reached the fjords, nor is there any evidence of ice streams in the adjacent fjords; the glaciers were no longer merged between areas. Younger moraine ridges are found on the mountain sides below the plateaus with their terminal moraines in the valleys.

Relative dating of the individual younger advances has not been possible and therefore it cannot be established whether the whole period of the Milne Land Stages should be regarded as one of oscillatory retreat, or whether, in fact, it comprises two distinct periods of advance with an intervening period of retreat after the older advance.

Small moraine ridges, outwash deposits and glacial striae indicate that during the younger advances small glaciers persisted in valleys which are now devoid of ice (areas I and II, around Bregnepynt).

Minimum relative dates for the youngest advance are given by shorelines cut in the proximal parts of the younger moraines at an altitude of $90 \mathrm{~m}$. In area II terminal moraine banks of a shape and composition similar to the banks previously mentioned are found to have been deposited at the same time as the formation of a shoreline at $90 \mathrm{~m}$; however, as a shoreline of the same altitude is found also behind these moraines, the deposition of and withdrawal from this last stronghold of the Milne Land Stages seems to have taken place very rapidly.

Sugden \& John (1965) have reported from Kjove Land (fig. 1) evidence of two glacier advances during which Nordvestfjord and Schuchert Flod valley contained major ice streams, the oldest being earlier than a shoreline at $134 \mathrm{~m}$, the younger contemporaneous with one at $101 \mathrm{~m}$ altitude. It seems likely that these two advances are equivalent to the oldest and one of the younger advances of the Milne Land Stages. It is also interesting to note that Lasca (1969), from Skeldal in Kong Oscars Fjord (150 km NNE of Bregnepynt), reported two major glacier advances during which Kong Oscars Fjord was occupied by ice streams; the younger of these occurred just before the formation of a marine delta at $110 \mathrm{~m}$ above present sea-level.

\section{Radiocarbon dates}

No absolute dating of the individual stages has been made. By extrapolation from a radiocarbon dated curve of uplift from Mesters Vig (Washburn \& Stuiver, 1962) Sugden \& John assumed an age of about 10000 years for their youngest advance, thus correlating it with the Fennoscandian Moraine from Younger Dryas time.

Radiocarbon dates obtained recently from the Scoresby Sund region (see later) seem to be in good agreement with this assumption. Thus the dates from Rypefjord and Gåsefjord (K-1459, K-1460) show that the fjords were ice-free at least 7000 years ago. The date of 8640 years BP for a shoreline at about $65 \mathrm{~m}$ on 
the Bjørneøer (K-1461) must be significant for Milne Land also, indicating that the Milne Land Stages were considerably older than this. The latter date, as well as one obtained by J. P. Schafer \& J. M. Hartshorn (Levin et al. 1965, p. 396) of 7900 \pm 350 years BP for a shoreline at $50 \mathrm{~m}$ in Schuchert Flod valley, both fall within the range of dates obtained from the same altitudes in Mesters Vig (Washburn \& Stuiver, 1962) and the neighbouring Skeldal (Lasca, 1969). This might indicate that these areas lie near the same isobase which would provide a means of correlation between the regions.

\section{Glacial deposits older than the Milne Land Stages}

Erratic boulders have been found in all parts of the region visited, the highest altitude reached being $800 \mathrm{~m}$. However, it was observed that there is a distinct difference in the decomposition of the country rock (coarse-grained granite, sandstone and micaceous shale) outside and inside the line of moraines of the Milne Land Stages. Outside these moraines decomposition crusts deeper than $1 \mathrm{~m}$ were observed, whereas inside the ridges no decomposition was observed. Mass-wasting features also are far more common outside than inside these moraines. This seems to indicate that areas outside the moraines have been exposed to subaerial weathering for a very long time.

\section{Glacial deposits younger than the Milne Land Stages}

In area IV, to the north of Mudderbugt, a system of distinct lateral and terminal moraines was found. These were apparently contemporaneous with a shoreline at $35 \mathrm{~m}$; this is the only evidence yet available for a glacial advance of this age.

Terminal moraines which, from their fresh appearance, were judged to be historical, were found $1-2 \mathrm{~km}$ in front of the two glaciers visited (areas II and III). It was not possible to date them, but from a comparison with aerial photographs the glaciers appear to have been stationary at least since 1950.

\section{Shorelines}

The features here interpreted as marine shorelines are all cliffs with boulders at their foot; often extensive deposits of grey silt were found sloping down from the boulder line. The individual stretches of shoreline can be followed unbroken for $1500-2000 \mathrm{~m}$, and a shoreline at altitudes from 88 to $95 \mathrm{~m}$ was found along $15 \mathrm{~km}$ of a valley in area II, being interrupted only where the sides of the valley were steep. Old drainage patterns were developed in relation to water levels at the same altitudes as the shorelines, thus outwash deltas were built up to this altitude. 
As no marine fossils have been found along the shorelines, an alternative explanation would be that they were formed by extensive ice dammed lakes developed by the damming of fjord arms by piedmont glaciers descending from the sides. This process is thought to be the explanation of extensive shorelines in the interior of the Kong Oscars Fjord - Kejser Franz Joseph Fjord region to the north of Scoresby Sund (Bretz, 1935; Flint, 1948; Sugden, 1962). However, in the Scoresby Sund region the fjords are wide and the coastal zone generally low, not providing conditions suitable for piedmont glaciers, and as no evidence has been observed for ice damming a marine origin is thought to be the most likely explanation for the shorelines.

Assuming that the shorelines are marine, another problem arises: are they tilted in the region? The radiocarbon dates from the region are still too sparse to give any evidence on this problem, but as no tilting has been observed in the longest stretches of shoreline, tilting is thought to be negligible, at least within the individual areas. Possibly some of the difference in the shoreline dating of events in different areas could be explained by tilting.

No shorelines have been observed at higher altitudes than those here mentioned. This appears to be due to the effect of the mass-wasting in areas outside the domain of the glaciers of the Milne Land Stages; the marine limit in the region is thus not yet known.

\section{References}

Bay, E. 1896: Geologien ved Scoresby Sund. Meddr Grønland 19, 145-189.

Bretz, J. H. 1935: Physiographic studies in East Greenland. In Boyd, L. A. (editor) The fiord region of East Greenland. Spec, publs Am. Geogr. Soc. 18, 159-267.

Cruikshank, J. G. \& Colhoun, E. A. 1965: Observations on pingos and other landforms in Schuchertdal, Northeast Greenland. Geogr. Ann. 47a, 224-237.

Flint, R. F. 1948: Studies in glacial geology and geomorphology (1937). In Boyd, L. A. (editor) The coast of Northeast Greenland. Spec. publs Am. Geogr. Soc. 30, 91-211.

Geological Survey of Greenland (in press) Quaternary Map of Greenland.

Lasca, N. P. 1969: The surficial geology of Skeldal, Mesters Vig. Meddr Gronland 176, 3, 59 pp.

Levin, B., Ives, P. C., Oman, C. L. \& Rubin, M. 1965: U.S. Geological Survey radiocarbon dates VIII. Radiocarbon 7. 372-398.

Nordenskiöld, O. 1907: On the geology and physical geography of East Greenland. Meddr Gronland 28, 151-285.

Sugden, J. 1962: The strandlines in the Dammen region of Alpefjord. Geogll J. 128, 43-48.

Sugden, D. E. \& John, B. 1965: The raised marine features of Kjove Land, East Greenland. Geogrl J. 131, 235-247.

Thorson, G. 1934: Contributions to the animal ecology of the Scoresby Sund Fjord complex (East Greenland). Meddr Gronland 100, 3, 69 pp.

Washburn, A. L. \& Stuiver, M. 1962: Radiocarbon-dated postglacial delevelling and its implications. Arctic 15, 66-73. 